\title{
Hubungan Tipe Thalassemia $\beta$ serta Polimorfisme c.-582 A>G Promotor Gen HAMP dan Status Besi thalassemia $\beta$ Berat Baru
}

\author{
Susi Susanah, Ponpon Idjradinata \\ Departemen Ilmu Kesehatan Anak Fakultas Kedokteran Universitas Padjadjaran \\ Rumah Sakit Dr. Hasan Sadikin Bandung
}

\begin{abstract}
Abstrak
Kelebihan besi merupakan penyebab morbiditas dan mortalitas penderita thalassemia $\beta$ berat. Terdapat berbagai faktor yang memengaruhi status besi thalassemia $\beta$ berat. Penelitian ini bertujuan menganalisis hubungan tipe thalassemia $\beta$ serta polimorfisme c.-582 A>G promotor gen hepcidine antimicrobacterial peptide (HAMP) dengan status besi thalassemia $\beta$ berat baru. Penelitian dengan metode potong lintang dilakukan di Rumah Sakit Dr. Hasan Sadikin/Fakultas Kedokteran Universitas Padjadjaran Bandung selama November-Desember 2012. Subjek penelitian adalah penderita thalassemia $\beta$ berat yang baru didiagnosis berdasarkan pemeriksaan klinis dan laboratorium. Subjek belum pernah mendapatkan transfusi darah dan memiliki kadar C-reactive protein normal. Status besi dinilai dengan mengukur kadar feritin serum (FS) dan saturasi transferin (ST). Analisis statistik yang digunakan adalah uji-t, Uji Mann-Whitney, dan uji chi-kuadrat. Didapatkan 29 subjek thalassemia $\beta$ berat baru, 24 thalassemia $\beta$ mayor dan 5 thalassemia $\beta / \mathrm{HbE}$ berat. Tidak ada perbedaan status besi antara kedua tipe thalassemia $\beta$ berat baru maupun antara yang mengalami polimorfisme dan yang tidak mengalami polimorfisme c.-582 A $>$ G promotor gen $\operatorname{HAMP}(\mathrm{p}>0,05)$. Simpulan, tipe thalassemia $\beta$ berat dan polimorfisme c.-582 A $>$ G promotor gen HAMP tidak berhubungan dengan status besi penderita thalassemia $\beta$ berat yang baru didiagnosis. [MKB. 2015;47(3):192-98]
\end{abstract}

Kata kunci: Feritin, polimorfisme c.-582 A>G promotor gen HAMP, saturasi transferin, thalassemia $\beta$ berat

\section{Association of $\beta$-thalassemia Type and Polymorphisms of c.-582 A>G Promoter HAMP Gene and Iron Status in Newly Diagnosed Severe $\beta$-thalassemia}

\begin{abstract}
Iron overload is the common cause of morbidity and mortality in severe $\beta$-thalassemia patients. Many factors influence the iron status in severe $\beta$-thalassemia. This study aimed to analyze the association of $\beta$-thalassemia type, polymorphism c.-582 A>G promotor hepcidine antimicrobacterial peptide (HAMP) gene, and iron status in newly diagnosed severe $\beta$-thalassemia. A cross-sectional study was performed at Dr. Hasan Sadikin General Hospital/Faculty of Medicine, Universitas Padjadjaran Bandung from November to December 2012. Subjects were newly diagnosed severe $\beta$-thalassemia patients who were diagnosed based on clinical manifestation and laboratory examination. Subjects had not received any blood transfusion before and had normal CRP level. Transferrin saturation (TS) and serum ferritin (SF) levels indicate iron status. The statistical analysis was performed using t test, Mann-Whitney, and Chi square test. Twenty nine subjects were diagnosed as newly severe $\beta$-thalassemia, $24 \beta$-thalassemia mayor and 5 with severe $\beta$-thalassemia/HbE. There was no difference in the iron status between the two types of severe $\beta$-thalassemia and between those with and without polymorphism of c.-582 A $>$ G promotor HAMP gene in newly diagnosed severe $\beta$-thalassemia ( $>0.05$ ). In conclusiosn, the $\beta$-thalassemia type and polymorphism of c.-582 A $>$ G promotor HAMP gene do not associate with the iron status in newly diagnosed severe $\beta$-thalassemia patients. [MKB. 2015;47(3):192-98]
\end{abstract}

Key words: Ferritin, polymorphism of c.-582 A>G promotor HAMP gene, severe $\beta$-thalassemia, transferrin ration

Korespondensi: Susi Susanah, dr., Sp.A(K), Departemen Ilmu Kesehatan Anak Fakultas Kedokteran Universitas Padjadjaran/ Rumah Sakit Dr. Hasan Sadikin Bandung, Jalan Pasteur No. 38 Bandung, mobile 0818428354, e-mail susi_rshs@yahoo.co.id 


\section{Pendahuluan}

Thalassemia dan juga hemoglobinopati lain merupakan kelainan genetik yang terbanyak ditemukan, termasuk di Indonesia dan saat ini telah menjadi masalah kesehatan dunia. ${ }^{1}$ Dengan jumlah penduduk 240 juta jiwa, bila angka pembawa sifat thalassemia $\beta$ adalah 3-10\%, setiap tahunnya, di Indonesia diperkirakan akan lahir sekitar 3.000 bayi penyandang thalassemia $\beta$ mayor. ${ }^{2}$ Penyebab morbiditas dan mortalitas penderita thalassemia $\beta$ berat adalah kelebihan besi yang ditimbun pada organ tubuh, terutama pada jantung yang menyebabkan iron overload cardiomopathy. ${ }^{3}$ Keadaan seperti ini disebabkan masuknya besi lewat transfusi darah reguler dan peningkatan penyerapan besi di usus karena peningkatan aktivitas eritropoesis. ${ }^{4}$ Sebelumnya, dinyatakan bahwa beban besi untuk penderita thalassemia berat disebabkan oleh transfusi darah berulang, akan tetapi ditemukan bahwa sebagian penderita telah mengalami kelebihan besi lebih awal, artinya kelebihan besi yang terjadi sering tidak sesuai dengan jumlah darah yang diterima. Kelebihan besi pada thalassemia $\beta$ serta thalassemia $\beta / \mathrm{HbE}$ berat ditengarai lebih banyak disebabkan oleh karena peningkatan penyerapan besi di usus. ${ }^{4-9}$

Status besi pada thalassemia $\beta$ yang berat melibatkan peran banyak faktor, di antaranya peran hepsidin sebagai peptida suatu pengatur homeostasis besi dengan cara mengendalikan penyerapan besi, ekspresinya yang seharusnya meningkat pada keadaan kelebihan besi malah ditemukan menurun.-9 Penurunan ekspresi hepsidin diduga juga berhubungan dengan peran polimorfisme c. $-582 \mathrm{~A}>\mathrm{G}$ promotor gen hepcidin antimicrobacterial peptide (HAMP). ${ }^{10}$ Keadaan ini akan menyebabkan ekspresi hepsidin menurun sehingga menyebabkan peningkatan penyerapan besi di usus halus. ${ }^{10,11}$ Penelitian ini bertujuan menganalisis hubungan tipe thalassemia $\beta$ serta polimorfisme c.-582 $\mathrm{A}>\mathrm{G}$ promotor gen HAMP dengan status besi penderita thalassemia $\beta$ berat yang baru didiagnosis.

\section{Metode}

Penelitian dengan rancangan potong lintang dilakukan pada periode November sampai Desember 2012 di Departemen Ilmu Kesehatan Anak Rumah Sakit Dr. Hasan Sadikin (RSHS)/ Fakultas Kedokteran Universitas Padjadjaran (FKUP) terhadap penderita thalassemia $\beta$ berat baru. Persetujuan secara tertulis diperoleh dari orangtua/wali, dilakukan anamnesis, pemeriksaan fisis, dan pemeriksaan laboratorium. Persetujuan penelitian didapat dari Komite Etik Penelitian Kesehatan Fakultas Kedokteran Universitas Padjadjaran Bandung.

Pada semua subjek dilakukan pencatatan nama, tanggal lahir, jenis kelamin, ras, alamat, berat badan dan panjang/tinggi badan, riwayat keluarga, dan riwayat transfusi darah. Subjek merupakan penderita thalassemia $\beta$ berat baru yang didiagnosis berdasarkan anamnesis dan juga pemeriksaan fisis dapat mengindikasikan suatu thalassemia berat. Diagnosis ditegakkan berdasarkan hasil pemeriksaan darah rutin lengkap,indekseritrosit, morfologi darahtepi,dan dikonfirmasi oleh hasil analisis hemoglobin $(\mathrm{Hb})$ metode high performace liquid chromatography (HPLC). Subjek belum pernah mendapatkan transfusi darah dan memiliki kadar C-reactive protein (CRP) normal $(<6 \mathrm{mg} / \mathrm{dL})$. Status besi dinilai dengan mengukur kadar feritin serum (FS) dan saturasi transferin (ST). Pemeriksaan FS menggunakan metode immunoassay, sementara nilai ST diperoleh dengan cara membagi kadar besi serum dengan kadar total iron binding capacity (TIBC) dikalikan 100\%. Pada penelitian ini kadar FS dan ST dinyatakan meningkat bila kadarnya lebih tinggi daripada harga normal sesuai usia (nilai normal FS 2-5 bulan $=50-200$ $\mathrm{ng} / \mathrm{mL}, 6$ bulan-15 tahun=7-140 ng/mL; ST 2 bulan $=21-63 \%, 4$ bulan $=7-53 \%, 6$ bulan -2 tahun $=6-38 \%)$. Pemeriksaan polimorfisme c.$582 \mathrm{~A}>\mathrm{G}$ promotor gen HAMP pada penelitian ini melalui suatu proses isolasi deoxyribonucleic acid (DNA), polymerase chain reaction (PCR), dilanjutkan dengan digesti oleh enzim restriksi PCR- rapid fragment length polymorphism (PCRRFLP), dan sekuensing. Produk PCR diperiksa urutan basanya dengan menggunakan alat sekuenser, metode direct sequencing. Semua pengolahan analisis data menggunakan program komputer statistical product and service solutions (SPSS) versi 15.0 dengan menggunakan taraf kemaknaan sebesar 5\% (kemaknaan hasil uji: nilai $\mathrm{p}<0,05)$. Penelitian ini merupakan bagian dari penelitian utama yang berjudul "Peran tipe thalassemia $\beta$, kadar hepsidin serum, polimorfisme c.-582 $\mathrm{A}>\mathrm{G}$ promotor gen $H A M P$, dan kadar growth diffrentiation factor 15 pada status besi thalassemia $\beta$ berat baru".

\section{Hasil}

Selama periode penelitian diperoleh 29 subjek penderita thalassemia $\beta$ berat. Karakteristik 
Tabel 1 Karakteristik Subjek Penelitian

\begin{tabular}{|c|c|}
\hline Karakteristik & $\begin{array}{c}\text { Jumlah } \\
n=29\end{array}$ \\
\hline \multicolumn{2}{|l|}{ Jenis kelamin } \\
\hline Laki-laki & 14 \\
\hline Perempuan & 15 \\
\hline \multicolumn{2}{|l|}{ Usia diagnosis (bulan) } \\
\hline $0-12$ & 21 \\
\hline$>12-24$ & 3 \\
\hline$>24$ & 5 \\
\hline \multicolumn{2}{|c|}{ Tipe thalassemia $\beta$ (analisis $\mathrm{Hb}$ ) } \\
\hline Thalassemia $\beta$ mayor & 24 \\
\hline Thalassemia $\beta / \mathrm{HbE}$ & 5 \\
\hline \multicolumn{2}{|l|}{ Polimorfisme gen $H A M P$} \\
\hline \multicolumn{2}{|l|}{ Ada $(+)$} \\
\hline Genotipe AG & 8 \\
\hline Genotipe GG & 0 \\
\hline Tidak ada (-) & 21 \\
\hline \multicolumn{2}{|l|}{ Status besi feritin serum } \\
\hline Meningkat & 23 \\
\hline Normal & 6 \\
\hline \multicolumn{2}{|c|}{ Status besi saturasi transferin } \\
\hline Meningkat & 22 \\
\hline Normal & 7 \\
\hline
\end{tabular}

subjek penelitian dapat dilihat pada Tabel 1 .

Berdasarkan data di atas diperoleh bahwa pada penelitian ini subjek laki-laki dan juga perempuan hampir sama banyak. Sebagian besar $(24 / 29)$ penderita thalassemia $\beta$ berat yang baru didiagnosis berusia di bawah 24 bulan, 21/29 di antaranya didiagnosis pada usia di bawah usia 12 bulan. Berdasarkan hasil analisis $\mathrm{Hb}$ sebagian besar (24/29) diklasifikasikan sebagai thalassemia $\beta$ mayor (homozigot). Polimorfisme c.-582 A $>$ G promotor gen HAMP terdapat pada $8 / 29$ subjek yang semuanya heterozigot (AG). Sebanyak 23/29 (berdasarkan kadar FS) dan 22/29 (berdasarkan kadar ST) subjek telah mengalami peningkatan kadar besi pada saat pertama kali didiagnosis.

Dari hasil uji beda menggunakan uji-t untuk FS tidak terdapat perbedaan bermakna kadar FS rata-rata pada kelompok thalassemia $\beta$ mayor dengan thalassemia $\beta / \mathrm{Hb}$ E berat. Juga tidak terdapat perbedaan bermakna kadar ST rata-rata pada kelompok thalassemia $\beta$ mayor dengan thalassemia $\beta / \mathrm{Hb}$ E berat $(\mathrm{p}>0,05)$. Gambaran elektroforesis dari polimorfisme c.$582 \mathrm{~A}>\mathrm{G}$ promotor gen HAMP hasil PCR-RFLP dapat dilihat pada Gambar 1. Hasil sekuensing polimorfisme c.-582 A $>\mathrm{G}$ promotor gen HAMP dapat dilihat pada Gambar 2 dan Gambar 3.

Tabel 3 memperlihatkan tidak didapatkan perbedaan bermakna usia penderita thalassemia $\beta$ berat pada yang mengalami polimorfisme dengan yang tidak mengalami polimorfisme. Kadar FS rata-rata pada polimorfisme (+) lebih rendah bila dibanding dengan kelompok polimorfisme (-) $(379,7$ vs 435,6$)$. Sementara itu, kadar ST rata-rata pada kelompok polimorfisme $(+)$ lebih tinggi dibanding dengan kelompok polimorfisme (-) $(75,4$ vs 60,2$)$.

Uji beda menggunakan Uji Mann-Whitney untuk FS, tidak terdapat perbedaan bermakna FS rata-rata antara kelompok polimorfisme $(+)$ dan $(-)(p>0,05)$. Demikian pula dengan menggunakan uji-t untuk ST diperoleh bahwa tidak terdapat perbedaan bermakna ST ratarata antara kelompok polimorfisme $(+)$ dan polimorfisme $(-)(p>0,05)$.

\section{Pembahasan}

Pada penelitian ini didapatkan bahwa penderita thalassemia $\beta$ berat yang baru didiagnosis terjadi sama banyak pada anak laki-laki dan perempuan.

Tabel 2 Hubungan Tipe thalassemia $\beta$ berat dengan Status Besi

\begin{tabular}{llcccccc}
\hline Variabel & Tipe thalassemia & Rata-rata & Median & SB & Minimal & Maksimal & $\mathbf{p}^{*}$ \\
\hline Feritin & Thal $\beta$ mayor & 456,3 & 360,9 & 380,9 & 19,0 & 1824,0 & 0,106 \\
serum & Thal $\beta$ /HbE berat & 246,8 & 241,6 & 42,8 & 189,9 & 303,2 & \\
\multirow{2}{*}{ Saturasi } & T Thal $\beta$ mayor & 65,9 & 65,9 & 22,6 & 20,1 & 98,7 & 0,453 \\
transferin & Thal $\beta /$ HbE berat & 56,9 & 60,8 & 30,9 & 15,5 & 87,7 & \\
\hline
\end{tabular}

Keterangan: SB: simpangan baku; Thal: Thalassemia; *uji chi-kuadrat 
Susi S: Hubungan Tipe Thalassemia $\beta$ serta Polimorfisme c.-582 A>G Promotor Gen HAMP dan Status Besi thalassemia $\beta$

Tabel 3 Karakteristik dan Hubungan Polimorfisme Gen HAMP dengan Status Besi

\begin{tabular}{llcccccc}
\hline Variabel & Polimorfisme & Rata-rata & Median & SB & Minimal & Maksimal & $\mathbf{p}^{*}$ \\
\hline \multirow{2}{*}{ Usia } & Positif & 10,9 & 10,5 & 6,5 & 4,0 & 25,0 & 0,345 \\
& Negatif & 15,7 & 7,0 & 17,2 & 4,0 & 65,0 & \\
Feritin & Positif & 379,7 & 351,5 & 208,3 & 73,6 & 719,9 & 0,700 \\
serum & Negatif & 435,6 & 284,8 & 400,3 & 19,0 & $1.824,0$ & \\
\multirow{2}{*}{ Saturasi } & Positif & 75,4 & 82,3 & 21,1 & 42,7 & 98,7 & 0,270 \\
transferin & Negatif & 60,2 & 62,2 & 23,9 & 15,5 & 90,7 & \\
\hline
\end{tabular}

*Uji chi-kuadrat

Hal ini sesuai dengan karakteristik thalassemia yang merupakan kelainan genetik diturunkan mengikuti kaidah Mendel sehingga tidak ada berhubungan dengan jenis kelamin penderita. ${ }^{4,5}$ Sebagian besar penderita thalassemia $\beta$ berat ini baik yang thalassemia $\beta$ mayor maupun thalassemia $\beta / \mathrm{HbE}$ berat didiagnosis saat berusia kurang dari 12 bulan. Keadaan ini sesuai dengan yang dilaporkan Berdoukas dan Modell ${ }^{12}$ yang melaporkan usia pertama transfusi darah pada pasien thalassemia $\beta$ berat sebanyak $62 \%$ sebelum usia 1 tahun, $29 \%$ pada usia 1-2 tahun, dan $9 \%$ pada usia $>2$ tahun. Galanello dan Origa ${ }^{13}$ melaporkan bahwa thalassemia $\beta$ berat umumnya didiagnosis sebelum usia 2 tahun. Hal ini juga sesuai dengan patogenesis dan patofisiologi thalassemia $\beta$ berat yang kalau kelainannya berat, jika tanpa disertai pemodifikasi genetik yang bersifat meringankan, manifestasi klinis akan mucul pada awal kehidupan. ${ }^{4,5}$ Defek globin akan menyebabkan eritropoesis tidak efektif sehingga terjadi hemolisis berat yang mengakibatkan anemia berat. ${ }^{4-6}$

Sebanyak 5/29 subjek didiagnosis setelah usia $>24$ bulan, bahkan ada yang berusia 65 bulan. Pada subjek-subjek ini, manifestasi klinis tampak menyokong penampilan thalassemia $\beta$ berat, seperti facies Cooley, hepatosplenomegali yang sudah berat, gagal tumbuh, dan didukung oleh fakta bahwa setelah didiagnosis mereka ternyata memerlukan transfusi darah reguler, juga berdasarkan atas hasil analisis Hb-nya menunjukkan thalassemia $\beta$ berat. 4,5 Tampaknya keterlambatan diagnosis ini disebabkan oleh ketidaktahuan orangtua sehingga mereka tidak begitu memerhatikan anaknya yang mengalami pucat secara perlahan-lahan tanpa gejala klinis yang mengganggu aktivitas.

Pada penelitian ini didapatkan bahwa thalassemia $\beta$ berat didominasi oleh thalassemia

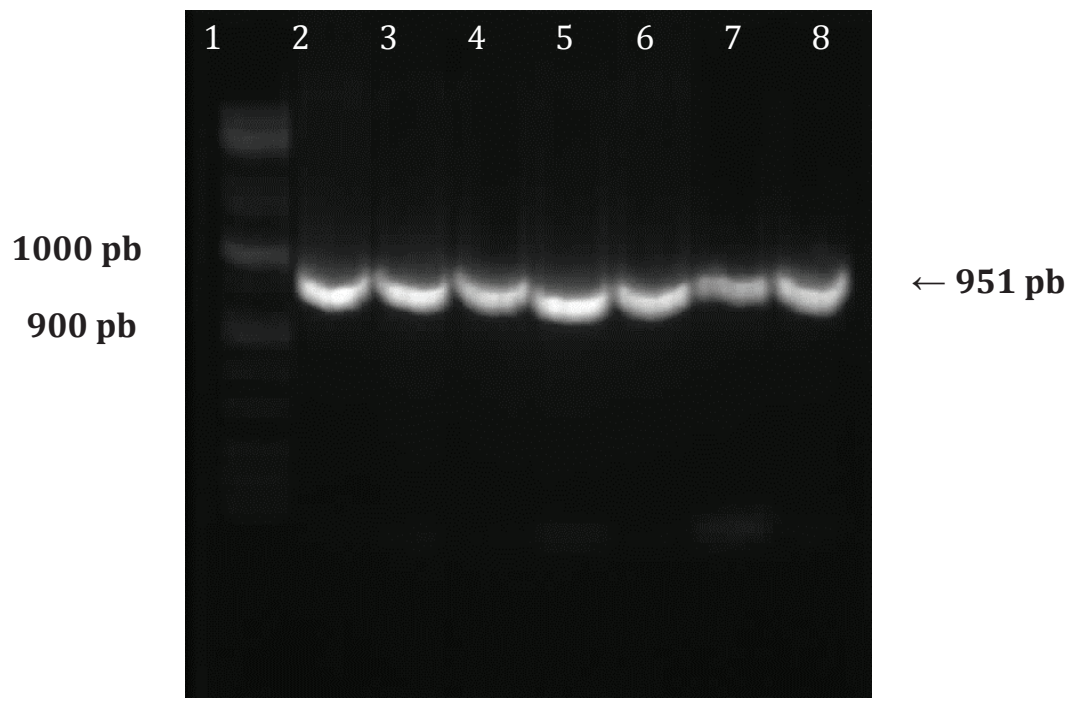

Gambar 1 Gambaran Elektroforesis Hasil PCR Regio c.-582A>G Promotor Gen HAMP

Keterangan: Lajur 1: Penanda molekuler ladder 100; Lajur 2-8: Produk PCR sebesar 951 pasangan basa $(\mathrm{pb})$ 
Genotipe AG

400 AAACAC C A C G T G C G G A T C

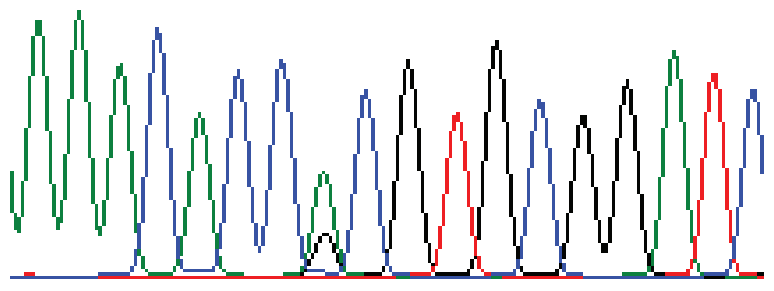

Gambar 2 Elektroforegram Hasil Sekuensing Regio Promotor Gen HAMP(Primer Forward)
Genotipe AA

\section{0 AAACAC CACG T G C G G A T '}

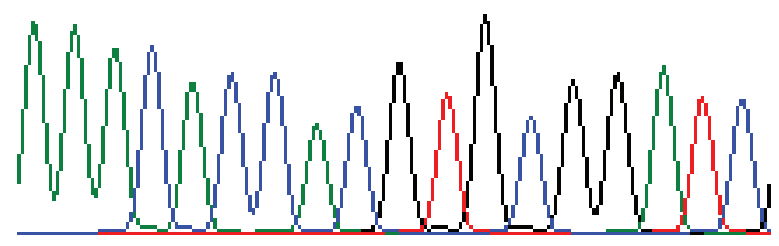

Gambar 3 Elektroforegram Hasil Sekuensing Regio Promotor Gen HAMP (Primer Reverse)

microbacterial peptide (HAMP), diekspresikan di dalam hati pada keadaan kelebihan besiterletak pada kromosom 19q13 itu. Ekpresinya diatur (upregulated) oleh hemojuvelin (HJV), reseptor transferin, dan protein hemokromatosis (HFE) melalui bone morphogenetic protein (BMP) signalling pathway, inflamasi melalui interleukin 6 (IL-6), dan sitokin-sitokin lain melalui Janus kinase/signal transducer and activator of transcription (JAK/STAT) signalling pathway. ${ }^{6,18,19}$ Ekspresi hepsidin dihambat oleh hipoksia dan peningkatan eritropoesis. ${ }^{6,8,9,18,19}$

Salah satu faktor genetik yang ditengarai dapat memengaruhi homeostasis besi adalah polimorfisme. Polimorfisme merupakan variasi urutan DNA yang menimbulkan keragaman genetik di dalam pool gene suatu populasi. Urutan asam amino pada protein ditentukan oleh informasi yang terdapat dalam gen yang disusun oleh DNA. Gen yang memiliki urutanurutan berbeda dianggap polimorfik. Bentuk yang berbeda ini disebut dengan istilah alel. Polimorfisme terbentuk melalui proses mutasi yang dapat terjadi karena substitusi, delesi, atau insersi pada urutan polinukleotida. Polimorfisme mempunyai pengaruh yang netral pada fungsi biologis, namun dalam beberapa kondisi dapat saja menyebabkan gangguan fungsi biologis. Hal ini terjadi karena perubahan pada susunan DNA yang bertanggungjawab pada coding (mengode) protein. Polimorfisme dapat juga ditemukan pada area DNA yang tidak mengode protein. Semakin berkembangnya pengetahuan biologi molekular dan juga peran polimorfisme bermanfaat dalam mendiagnosis serta tatalaksana suatu penyakit. Dalam populasi manusia ditemui perbedaan polimorfisme dalam urutan DNA yang diwariskan dalam jumlah besar dan hal ini berkaitan dengan 
suatu penyakit.

Saat ini telah ditemukan varian genetik c.-582 $\mathrm{A}>\mathrm{G}$ promotor gen HAMP pada thalassemia $\beta$ berat yang digambarkan merupakan modulator kelebihan besi. ${ }^{10}$ Penelitian Andreani dkk. ${ }^{10}$ menyimpulkan bahwa varian dari c.-582 $\mathrm{A}>\mathrm{G}$ promotor gen $H A M P$ yang berhubungan dengan peningkatan kadar besi di dalam hati dan feritin pada pasien thalassemia $\beta$ berat. Dengan demikian, polimorfisme ini ditengarai memiliki peranan dalam metabolisme besi sehubungan dengan variasi aktivasi transkripsional yang terjadi melalui E-boxes yang berlokasi dalam promotor. Penelitian oleh Parajes dkk. ${ }^{11}$ pada populasi orang Galicia yang normal di Spanyol mendapatkan bahwa varian dari c.-582 $A>G$ promotor gen HAMP tidak berhubungan dengan peningkatan kadar besi, transferin, atau feritin serum. Hasil ini didukung oleh penelitian in vitro yang mendapatkan hanya $10-20 \%$ pengurangan transaktivasi oleh alel c.-582G dibanding dengan alel c. $-582 \mathrm{~A}^{10}{ }^{10}$ Penelitian Bruno dkk..$^{20}$ di Italia mendapatkan bahwa polimorfisme c.-582 $A>G$ promotor gen $H A M P$ pada orang normal tidak berhubungan dengan peningkatan kadar feritin, sedangkan pada thalassemia berat varian G menyebabkan inhibisi ekspresi hepsidin, serta peningkatan penyerapan besi dan kadar feritin.

Berdasarkan data di atas dapat dilihat bahwa polimorfisme c.-582 A>G promotor gen HAMP terjadi pada 8/29 subjek. Untuk suatu kejadian polimorfisme, keadaan ini termasuk frekuensi yang cukup tinggi. Para peneliti melaporkan bahwa polimorfisme terjadi pada kurang dari $1 \%$ populasi.

Kadar FS rata-rata pada polimorfisme $(+)$ lebih rendah bila dibanding dengan kelompok polimorfisme (-) $(379,7$ vs 435,6 .), sedangkan kadar ST rata-rata pada kelompok polimorfisme $(+)$ lebih tinggi dibanding dengan kelompok polimorfisme (-) $(75,4$ vs 60,2$)$. Uji beda menggunakan uji Mann Whitney kadar FS tidak terdapat perbedaan yang bermakna antara kelompok polimorfisme $(+)$ dan $(-)(p>0,05)$, sementara uji beda dengan menggunakan uji-t diperoleh tidak terdapat perbedaan bermakna ST rata-rata antara kelompok polimorfisme $(+)$ dan polimorfisme $(-)(p>0,05)$. Hasil ini berbeda dengan yang dilaporkan Andreani dkk. yang pada penelitiannya mendapatkan bahwa polimorfisme c.-582 $\mathrm{A}>\mathrm{G}$ promotor gen HAMP meningkatkan risiko peningkatan kadar besi karena polimorfisme ini akan mengakibatkan ekspresi hepsidin menurun sehingga mampu meningkatkan penyerapan besi di usus halus. ${ }^{10}$

Sebanyak 2/29 subjek di antaranya memiliki kadar feritin serum $\geq 1.000 \mathrm{ug} / \mathrm{dL}$, yang artinya sudah indikasi untuk mendapatkan obat kelasi besi. Temuan ini mampu mengindikasikan bahwa pada sebagian penderita thalassemia $\beta$ berat kelebihan besi sudah dapat terjadi lebih awal, bahkan sebelum mendapatkan transfusi darah. Sebelumnya, dinyatakan bahwa beban besi penderita thalassemia berat disebabkan oleh transfusi darah berulang, tetapi ditemukan fakta bahwa sebagian penderita telah mengalami kelebihan besi lebih dini, artinya kelebihan besi yang terjadi sering tidak sesuai dengan jumlah darah yang diterima. Kelebihan besi pada thalassemia $\beta$ dan thalassemia $\beta / \mathrm{HbE}$ berat ditengarai lebih banyak disebabkan oleh peningkatan penyerapan besi di usus. Fakta ini mendukung pendapat bahwa ada mekanisme lain yang lebih berperan dalam mekanisme kelebihan besi pada penderita thalassemia $\beta$ berat, di antaranya adalah peningkatan penyerapan besi. Keadaan ini merupakan hal yang perlu dicermati sehubungan dengan tatalaksana pemberian kelasi besi yang sudah direkomendasikan oleh Thalassemia International Federation (TIF) yang menyatakan bahwa indikasi pemberian kelasi besi bila sudah mendapat 10-20 kali transfusi darah. ${ }^{16}$ Kelebihan besi pada thalassemia $\beta$ berat baru sudah dapat terjadi sejak dini sebelum mendapatkan transfusi darah reguler. Perlu dilaksanakan penelitian lebih lanjut mengenai faktor-faktor lain yang memengaruhi status besi thalassemia $\beta$ berat yang baru didiagnosis yang dapat dipakai sebagai parameter faktor risiko peningkatan kadar status besi penderita thalassemia $\beta$ berat.

Sebagai simpulan tipe thalassemia $\beta$ serta polimorfisme c.-582 $\mathrm{A}>\mathrm{G}$ promotor gen HAMP tidak memiliki hubungan dengan status besi thalassemia $\beta$ berat baru.

\section{Daftar Pustaka}

1. Whetherall DJ. The inherited diseases of hemoglobin are an emerging global health burden. Blood. 2010;115(22):4331-6.

2. Wahidiyat I, Wahidiyat PA. Genetic problems at present and their challenges in the future: Thalassemia as a model. Paediatr Indones. 2006;46(9-10):189-94.

3. Kremastinos DT, Farmakis D, Aessopos A, Hahalis G, Hamordaka E, Tsiapras D, dkk. Beta thalassemia cardiomyopathy: history, present consideration, and future perspective. Circ Heart Fail. 2010;3(3):4518. 
4. Rund D, Rachmilewitz E. Medical progress beta thalassemia. N Engl J Med. 2005;353:1135-46.

5. Cunningham MJ, Sankaran VG, Nathan DG, Orkin SH. The thalassemias. Dalam: Orkin SH, Nathan DG, Ginsburg D, Look AT, Fisher DE, Lux SE, penyunting. Nathan and Oski's hematology of infancy and childhood. Edisi ke-7. Philadelphia: Saunders; 2009. hlm. 1015-76.

6. Nemeth E, Ganz T. Regulation of iron metabolism by hepcidin. Annu Rev Nutr. 2006;26:323-42.

7. Kearney SL, Nemeth E, Neufeld EJ, Thapa D, Ganz T, Weinstein DA, dkk. Urinary hepcidin in congenital chronic anemias. Pediatr Blood Cancer. 2007;48(1):57-63.

8. Rivella S. Ineffective erythropoiesis and thalassemias. Curr Opin Hematol. 2009; 16(3):187-94.

9. Tanno $\mathrm{T}$, Miller JL. Iron loading and overloading due to erythropoiesis ineffective. Advance Hematol. 2010;2010:1-8.

10. Andreani M, Radio FC, Testi M, Bernardo C, Troiano M, Majore S, dkk. Association of hepcidin promoter c.-582 $\mathrm{A}>\mathrm{G}$ variant and iron overload in thalassemia major. Haematologica. 2009;94(9):1293-6.

11. Parajes S, Gonzales-Quintela A, Campos J, Quinteiro C, Dominguez F, Loidi L. Genetic study of hepcidin gene (HAMP) promoter and functional analysis of the c.-582 $A>G$ variant. BMC Genet. 2010,11:110.
12. Berdoukas V, Modell B. Transfusion dependent thalassemia: a new era. Med J Aust. 2008;188(2):68-9.

13. Galanello R, Origa R. Beta thalassemia. Orphanet J Rare Dis. 2010;5:11:1-15.

14. Data Klinik Thalassemia RSUP Dr. Hasan Sadikin Bandung, Juli 2011.

15. Data Pusat Thalassemia RSUPN Dr. Cipto Mangunkusumo Jakarta, Juli 2011.

16. Guidelines for the clinical management of thalassemia. Edisi ke-2, revisi. Nicosia: Thalassemia International Federation; 2008.

17. Fischer R, Harmatz PR. Non-invasive assessment of tissue iron overload. Hematology Am Soc Hematol Educ Program. 2009:215-20.

18. Peyssonnaux C, Zinkernagel AS, Schuepbach RA, Rankin E, Vaulont S, Haase VH, dkk. Regulation of iron homeostasis by the hypoxia-inducible transcription factors (HIFs). J Clin Invest. 2007;117(7):1926-32.

19. Camberlein E, Zanninelli G, Detivaud L, Lizzi AR, Sorrentino F, Vacquer S, dkk. Anemia in $\beta$-thalassemia patients targets hepatic hepcidin transcript levels independently of iron metabolism genes controlling hepcidin expression. Haematologica. 2008;93(1):1115.

20. Bruno F, Bonalumi S, Camaschella C, Ferrari $\mathrm{M}$, Cremonesi L. The c.-582 $\mathrm{A}>\mathrm{G}$ variant of the HAMP promoter is not associated with high serum ferritin levels in normal subject. Haematologica. 2010;95(5):849-50. 